\title{
Cardiac Arrest and Succesful Resuscitation after Massive Bleeding and Massive Blood Transfusion during Hemipelvectomy: Case Report
}

\author{
Hasan Koçoğlư ${ }^{*}$, Korhan Özkan², Senem Koruk ${ }^{3}$, Murat Demiroğlu ${ }^{4}$, Nihan Kurt Özden ${ }^{5}$ \\ Nursen Koltka ${ }^{5}$,̈̈ner Erdoğan ${ }^{6}$, Alperen Kısa ${ }^{7}$ \\ ${ }^{1}$ Prof., Istanbul Medeniyet University, Faculty of Medicine, Department of Anesthesiology and Reanimation, \\ Istanbul, Turkey \\ ${ }^{2}$ Assoc. Prof., Istanbul Medeniyet University, Faculty of Medicine, Department of Orthopedics and \\ Traumatology, Istanbul, Turkey \\ ${ }^{3}$ Assoc. Prof. Istanbul Medeniyet University, Faculty of Medicine, Department of Anesthesiology and \\ Reanimation, Istanbul, Turkey \\ ${ }^{4}$ Specialist, Istanbul Medeniyet University Göztepe Education and Research Hospital, Orthopedics and \\ Traumatology Clinic, Istanbul, Turkey \\ ${ }^{5}$ Specialist, Istanbul Medeniyet University Göztepe Education and Research Hospital, Anesthesiology and \\ Reanimation Clinic, Istanbul, Turkey \\ ${ }^{6}$ Specialist, Muş State Hospital, Anesthesiology and Reanimation Clinic, Muş, Turkey \\ ${ }^{7}$ Specialist, Afşin State Hospital, Anesthesiology and Reanimation Clinic, Kahramanmaraş, Turkey
}

*Corresponding Author: Prof. Dr Hasan Koçoğlu, Faculty of Medicine, Department of Anesthesiology and Reanimation, Istanbul Medeniyet University, Istanbul, Turkey, E-mail: hasankocoglu@yahoo.com

\section{INTRODUCTION}

Hemipelvectomy is a complex and techniqually difficult procedure. Extensive tissue trauma of surgery and major blood loss are main problems that can be encountered during these operations (1). Massive bleeding (loss of entire blood volume equivalent within 24 hours or loss of $50 \%$ of blood volume within 3 hours or continuing blood loss of $150 \mathrm{ml} / \mathrm{min}$, or continuing blood loss of $1.5 \mathrm{ml} / \mathrm{kg} / \mathrm{min}$ over 20 $\mathrm{min}$ ) is the major cause of perioperative cardiac arrest in major noncardiac operations in noncardiac patients $(2,3)$. Massive transfusion is defined as the transfusion of more than 10 units of packed red blood cells within 24 hour or replacement of one entire blood volume within 24 hour or transfusion of more than 4 units of packed red blood cells in 1 hour when on-going need is foreseeable or replacement of $50 \%$ of 2. CASE REPORT total blood volume within 3 hour (4). Massive transfusion itself may be harmful to patints causing serious problems such as acidosis, coagulopathy, electrolyte abnormalities, hypothermia, citrate toxicity, and transfusionassociated acute lung injury (5). In case of perioperative cardiac arrests, management and resuscitation is often difficult due to the surgical settings and the position of the patient. The reported survival rate after intraoperative cardiac arrest is $34,5 \%$, and more than $70,0 \%$ of surgical patients undergoing CPR die in 30 postoperative days or less $(3,6)$. We aimed here to present a case of hemipelvectomy operation because of chondrosarcoma of the femur who have had massive bleeding, massive blood transfusion, cardiac arrest and succesful resuscitation perioperatively.

Table1. Blood Gas Analysis Results

\begin{tabular}{|c|c|c|c|c|}
\hline & Intraoperative & $\begin{array}{c}\text { Postoperative 1 } \\
\text { hour }\end{array}$ & $\begin{array}{c}\text { Postoperative 4 }^{\text {th }} \\
\text { hour }\end{array}$ & $\begin{array}{c}\text { Postoperative 1 }^{\text {st }} \\
\text { day }\end{array}$ \\
\hline $\mathrm{pH}$ & 7.15 & 7.16 & 7.28 & 7.37 \\
\hline $\mathrm{PaCO}_{2}(\mathrm{mmHg})$ & 36.7 & 45.8 & 34.6 & 38.4 \\
\hline $\mathrm{PaO}_{2}(\mathrm{mmHg})$ & 387 & 550 & 186 & 142 \\
\hline $\mathrm{Base} \mathrm{Excess}(\mathrm{mEq} / \mathrm{L})^{\mathrm{E}}$ & -14.7 & -11 & -3.5 & -0.8 \\
\hline $\mathrm{HCO}_{3}(\mathrm{mmol} / \mathrm{L})$ & 12.6 & 16.2 & 21.3 & 23.5 \\
\hline Lactate $(\mathrm{mmol} / \mathrm{L})$ & 7.2 & 10.7 & 2.8 & 1.4 \\
\hline
\end{tabular}


A forty year otherwise healthy male patient was planned to have internal hemipelvectomy with total femur resection followed by total femoral and ice cone prosthesis implantation due to chondrosarcoma with involvement of femur and acetabulum. The patient was evaluated preoperatively and prepared for the operation with the ASA (Americah Society of Anesthesiologists) risk of I after getting informed consent from the patient. In the operation room the patient was monitored (ECG, peripheral arterial oxygen saturation, arterial blood pressure throgh radial artery, temperature through nasopharyngeal probe). After intravenous cannulation (two 18 G cannulas, one $16 \mathrm{G}$ cannula, and central vein catheterisation through right internal jugular vein) anestetic induction was performed with 2 $\mathrm{mg} / \mathrm{kg}$ propofol (Propofol, Fresenius Kabi, Lake Zurich, Switzerland), $1 \mathrm{mg}$ midazolam (Dormicum, Deva Holding, İstanbul, Turkey) and $40 \mu \mathrm{g}$ fentanyl (Fentanyl Citrate, Vem İlaç, İstanbul, Turkey) intravenously. Endotracheal intubation was performed after having muscle relaxation with rocuronium (Esmeron, Organon, Istanbul, Turkey) (iv, $0,5 \mathrm{mg} / \mathrm{kg}$ ). About half an hour after the beginning of surgery siezing of blood started from the muscles of wide surgical area. After getting blood gas analysis packed red blood cell (PRBC) was started to be given to the patient since the hemoglobin level was below 8 gr/dL. Patient continued to sieze, and we keep on transfusing blood together with fresh frosen plasma by controlling blood gasses (Table 1) and hematocrit level together with hemodynamic parameters. During the third hour, systolic blood pressure decreased below Table2. Laboratory Results
$90 \mathrm{mmHg}$, and continued to be below $90 \mathrm{mmHg}$ in spite of fluid resuscitation and inotropic support (dopamin $0.1 \mu \mathrm{g} / \mathrm{kg} / \mathrm{hr}$, noradrenalin 0.1 $\mu \mathrm{g} / \mathrm{kg} / \mathrm{hr}$ ). The femur was totally exctracted with internal hemipelvectomy within the fourth hour, and the surgeons started to perform prosthetic implantation. However, during this time blood presure decreased below 60, and continued to decrease in spite of fluid overload and inotropic drug infusions. The temperature of the patient was $35^{\circ} \mathrm{C}$. At the beginning of the fifth hour ventricullar fibrillation appeared in ECG. We immeditely started to perform cardiac massage while the patient was in left lateral position (one anesthesiologist stabilised patient from the back and the other one performed cardiac massage) until defibrillator became ready. We defibrilated the heart and continued to performe external cardiac massage. At this time surgeons decided to postpone the implantation, and started to suture the incision immediatly. CPR was performed for about ten minutes, and cardiac massage was stopped as soon as normal sinus rhythm appeared in the monitor. His blood pressure at that time was about $100 / 60 \mathrm{mmHg}$, $\mathrm{pH}$ was 7.5 , and lactate level was above 7 $\mathrm{mmol} / \mathrm{L}$. Patient was transferred to the intensive care unit, mechanically ventilated for about 15 hours, and then extubated without any problem. Fibrinogen (totally 4 gr) (Haemocomplettan-P, Farmatek İlaç, İstanbul, Turkey) was given intravenously (totally 8 gr within postoperative three days) since the fibrinogen level was found to be very low (Table 2) in intensive care unit. The amount of bleeding was about $4000 \mathrm{ml}$ totally.

\begin{tabular}{|c|c|c|c|c|}
\hline & Preoperative & $\begin{array}{c}\text { Postoperative 1 } \\
\text { hour }\end{array}$ & $\begin{array}{c}\text { Postoperative 4 }^{\text {th }} \\
\text { hour }\end{array}$ & $\begin{array}{c}\text { Postoperative 1 }^{\text {st }} \\
\text { day }\end{array}$ \\
\hline Creatinine $(\mathrm{mg} / \mathrm{dL})$ & 0.96 & 0.68 & 0.92 & 0.83 \\
\hline Sodium $(\mathrm{mEq} / \mathrm{L})$ & 138 & 144 & 142 & 141 \\
\hline Potasium $(\mathrm{mEq} / \mathrm{L})$ & 4.8 & 3.4 & 3.3 & 3,7 \\
\hline Calcium(mEq/L) & 9 & 5,9 & 9,7 & 9,4 \\
\hline Albumin $(\mathrm{g} / \mathrm{dL})$ & 3,6 & 1,1 & 1,9 & 3,2 \\
\hline WBC (count per $\mu \mathrm{L})$ & 11000 & 12100 & 11900 & 8300 \\
\hline Hemoglobin $(\mathrm{gr} / \mathrm{dL})$ & 11,2 & 7,1 & 11,4 & 22 \\
\hline Hematocrit $(\%)$ & 34 & 20 & 35 & 157000 \\
\hline Platelet $($ count per $\mu \mathrm{L})$ & 366000 & 14900 & 30500 & 17,5 \\
\hline Prothrombin time $(\mathrm{sec})$ & 14,9 & 31,2 & 27,1 & 1,44 \\
\hline INR & 1,18 & 2,91 & 2,45 & 62,2 \\
\hline aPTT $(\mathrm{sec})$ & 32,7 & 82,4 & $>140$ & 396 \\
\hline Fibrinogen $(\mathrm{mg} / \mathrm{dL})$ & - & 79 & - & \\
\hline
\end{tabular}

WBC: White blood count, INR: International normalized ratio, aPTT: Partial thromboplastin time (activated) 
A total of $9000 \mathrm{ml}$ of crystalloid solution, 2000 $\mathrm{ml}$ of colloid solution, 10 units of PRBC, 4 units of FFP were transfused, and a total of $1000 \mathrm{ml}$ of urine output was observed during the whole period of operation. Femur implantation operation was performed 3 weeks after the first operation, and since than the patient is being walking well with his implanted femur.

\section{DISCUSSION}

The main cause of perioperative cardic arrest during noncardiac surgery in noncardiac patients reported to be mostly due to bleeding, similar to our case (3). Other factors like hypotermia and long duration of surgical time may also contribute cardiac arrest to occur. The rate and amount of blood loss during hemipelvectomy operations is usually very high. Aggressive resection and limb salvage surgery for pelvic tumors are reported to be technically difficult because of the complex anatomy of the pelvic region and the typically large tumor size at presentation. Pelvic instability, hemorrhage, wound infections, nerve and visceral damage are the main complications of hemipelvectomy. Massive haemorrhage is a major concern among these complications $(7,8)$. Molnar et al. (1) investigated 49 cases of hemipelvectomy, and reported that the operations had been long (90 to 600 minutes), median crystalloid requirement had been $8500 \mathrm{ml}$, and a median of seven units of PRBC had been transfused. Large bore intravenous sheats together with central venous and intra arterial pressure monitoring, as we performed, was necessary for the management of blood loss during operation. In spite of these precautions our patient had cardiac arrest which may be due to both blood loss and hypothermia. In our case we encountered massive bleeding, intraoperative massive transfusion, intraoperative cardiac arrest, and performed succesful CPR.

Management of cardiac arrest, either in hospital setting or in non-hospital setting, are governed by guidelines prepared by related associations like international liaison committee on resuscitation (ILCOR). However, existing guidelines are not comprehensive enough to cover deeply the specific aspects. Evidence based guidelines and standardized treatment algorithms addressing the particularities of perioperative cardiac arrest would be helpful (7). In our case, the position of patient was not suitable for cardiac massage to perform. The surgeons had to continue to handle the case (otherwise bleeding would continue) while anesthesiologists were performing CPR. We performed cardiac massage wihout changing the position, because it would be very difficult to birng the patient to supine postion which would cause CPR to be delayed and surgery to stop closure of incission. We were able to see the blood pressure on the screen generated by cardiac massage, and the systolic arterial blood pressure was always above $90 \mathrm{mmHg}$ during CPR. This effective cardiac massage and the fast closure of surgical area may be the main factors affecting the patient to survive.

As a result we conclude that during hemipel vectomy operations it should be kept in mind that the amount and the rate of bleeding may be so high that huge amount of fluid infusion and blood transfusion may be needed, metabolic problems such as acidosis may appear, and cardiac arrest may develop in spite of all efforts. In case of cardiac arrest early massage and fast closure of surgical area may be helpful for patient to survive.

\section{REFERENCES}

[1] Molnar R, Emery G, Choong PFM. Anaesthesia for hemipelvectomy-a series of 49 cases. Anaesth Intensive Care. 2007; 35: 536-543.

[2] Meißner A., Schlenke P. Massive Bleeding and Massive Transfusion. Transfus Med Hemother. 2012; 39: 73-84.

[3] Sprung J, Warner ME, Contreras MG, Schro eder DR, Beighley CM, Wilson GA, Warner DO. Predictors of survival following cardiac arrest in patients undergoing noncardiac surgery. Anesthesiology. 2003; 99: 259-269.

[4] Patil V, Shetmahajan M. Massive transfusion and massive transfusion protocol. Indian $J$ Anaesth. 2014; 58: 590-595.

[5] Sihler KC, Napolitano LM. Complications of massive transfusion. Chest. 2010; 137:209-220.

[6] Kazaure HS, Roman SA, Rosenthal RA, Sosa JA. Cardiac arrest among surgical patients: an analysis of incidence, patient characteristics, and outcomes in ACS-NSQIP. JAMA Surg. 2013; 148:14-21.

[7] Kunisada T, Choong PF. Major reconstruction for periacetabular metastasis: early complic ations and outcome following surgical treatm ent in 40 hips. Acta Orthop Scand. 2000; 71: 585-590. 
Cardiac Arrest and Succesful Resuscitation after Massive Bleeding and Massive Blood Transfusion during Hemipelvectomy: Case Report

[8] Tang X, Guo W, Yang R, Tang S, Ji T. Evalua tion of blood loss during limb salvage surgery for pelvic tumours. Int Orthop. 2009; 33: 751756.
[9] Hinkelbein J, Andres J, Thies KC, De Robertis E. Perioperative cardiac arrest in the operating room environment: a review of the literature. Minerva Anestesiol. 2017; 83: 1190-1198.

Citation: Hasan Koçoğlu, Korhan Özkan, Senem Koruk, Murat Demiroğlu, Nihan Kurt Özden, Nursen Koltka et al. Cardiac Arrest and Succesful Resuscitation after Massive Bleeding and Massive Blood Transfusion during Hemipelvectomy: Case Report. ARC Journal of Orthopedics. 2018; 3(1):1-4. doi:dx.doi.org/ 10.20431/2456-0588.0301001.

Copyright: () 2018 Authors. This is an open-access article distributed under the terms of the Creative Commons Attribution License, which permits unrestricted use, distribution, and reproduction in any medium, provided the original author and source are credited. 